\title{
Relationship between Financial Sector Development and Sustainable Economic Development: Time Series Analysis from Pakistan
}

\author{
Sofia Anwar \\ Assistant Professor, Deptt. of Economics, University of Sargodha,Sargodha, Punjab Pakistan \\ E-mail:sofia_ageconomist@yahoo.com \\ Ghulam Shabir \\ Graduate student, Deptt. of Economics, University of Sargodha, Sargodha, Punjab Pakistan \\ E-mail:shabir_ecb@yahoo.com \\ Zakir Hussain \\ Professor, Deptt. of Economics, University of Sargodha,Sargodha, Punjab Pakistan \\ E-mail:Zakir_rana@yahoo.com
}

\begin{abstract}
The study empirically investigated the contribution of financial sector in sustainable economic development of Pakistan. Annual data were used from the period of 1973 to 2007 . Main objectives were to analyze the long run relationship between financial sector development and sustainable economic development along with direction of causality between both. Auto Regressive Distributed Lag (ARDL) bound testing technique for cointegration was applied to estimate the long run relationship. A stable long run relationship was found between financial sector indicators and the sustainable economic development. Error Correction coefficient was statistically significant. It was concluded that financial sector had positive impact on the sustainable economic development in short run as well as in the long run. Causality test revealed that financial sector development was the basis for economic development.
\end{abstract}

Keywords: Sustainable economic development, Financial sector, Cointegration

JEL: E44, N25, O16

\section{Introduction}

In the past decade the financial sector had gone under large transformation in many countries of the world. Deregulation, privatization and openness had brought revolution in this sector. This resulted in many findings related to importance of financial sector developments in prompting the economic development of a nation.(Note 1)

Here comes a question that either this development in financial sector has caused sustainable development in developing countries; or the pace of development is going to initiate the development in financial sector.

It is true that a well-developed, efficient, organized and viable financial system is a necessary condition for the economic development in any economy. The financial sector occupied a crucial place in performing the development activities and acted as a catalyst to economic growth. Countries with developed banking sector and dynamic stock markets grew faster over the period compared with the countries had lagged financial system(Levine, 1997).The effects of technological changes had expanded firm's financial demand and these changes had increased requirements for financial intermediaries. Financial Intermediaries allocated funds to those projects where the marginal productivity of capital was maximum, thus financial sector caused the economic growth by increasing the productivity of capital. Development of the banking sector and the stock market were highly correlated with the economic development and both sectors exerted an important impact on development of a country (Beck et al.2000). Further, the financial sector played a very important role in mobilizing and better utilization of saving (Ang, 2008). Financial sector utilized these resources to increase capital formation through the provision of a wide range of financial tools to meet different requirements of borrowers and lenders.

The financial sector of Pakistan also witnessed revolutionary changes. A broad based program of reforms was launched since 1990s but the pace of these reforms increased manifold since 2000. The banking sector in Pakistan had been transformed from a sluggish state- owned sector to a dynamic private sector. The State Bank of Pakistan took a number of steps to further enhance the pace of this transformation process of the development of financial sector in the country.

Substantial literature existed on the debate of the financial sector development contribution towards economic development. Historically, Bagehot (1873) and Schumpeter (1912) highlighted the role of the financial sector in economic development. Levine and Zervos (1998) and King and Levine (1993) analyzed the contribution of financial sector development on output growth in cross-countries analysis. Stock market liquidity and banking sector development indicators showed positive correlation with economic growth in both short run and long run scenario in most countries of the study. Arestis et al. (2001), Shan et al. (2002), and Abu-Bader et al. (2005) explored the link between financial sector development and economic growth Bank-based model contributed more to output growth in long run than the stock market based model. Causality results showed finance led growth. Loayza and Ranciere 
(2002), Andries et al. (2003), Seetanah (2007), Jalil and Ma (2008) and Khan et al. (2005) used Autoregressive distributed lag (ARDL) technique was used to estimate the short run and long run effects of financial sector development on economic growth. A positive long-run effect was found of financial intermediation on output growth. Ang (2008) attempted to analyze the role of financial sector development and liberalization on the income inequalities in India. Khan and Qayyum (2004) and Shahbaz et al. (2008) investigated the impact of trade and financial development on economic growth in Pakistan. With Bound testing approach of cointegration; it was found that financial sector indicators and real interest rate had a positive and significant effect on economic growth. Previous studies used GDP, real GDP per capita or GNP as the proxies for economic growth but these studies ignored the debt burden and exports. This paper will use external debt to exports ratio as the proxy of sustainable economic development and examine the contribution of financial sector development towards the economic development of the country and also the direction of causality between them.

The paper is structured as follows: In the next section the main findings of the existing literature are given, section 2 is for description of research methodology and data used. In section 3 the empirical findings are provided and finally, the main findings of the study are summarized in concluding section.

\section{Data and Research Methodology}

The most important and critical requirement for the research is the provision of an accurate and consistent data along with an appropriate methodology. Therefore, the use of systematic and most suitable technique in conducting any empirical study was imperative. Basic hypotheses, data selection, model specification, variables description and procedures were considered the basic ingredients of methodology. All these key-components of methodology are discussed in this section.

\subsection{Data and Data sources}

The annual time series data were used over the period of (1973-2007). The data were taken from International Financial Statistics (IFS), World Development Report, World Bank, Pakistan Economic Survey different issues, Handbook of Statistics on Pakistan Economy (2005), State Bank of Pakistan (SBP). World Development Indicators (WDI), Global Development finances.

\subsubsection{Description of the variables}

The selection of key variables to indicate the level of financial sector development is a very difficult task. There were so many alternative indicators that could affect the financial sector development. Numerous indicators are used in various studies related to the topic of financial development and economic growth. Three indicators are selected from the banking sector and one proxy is developed to capture stock market development.The first indicator is the Ratio of M2 minus Currency in Circulation to Nominal GDP $(M G)$. M2 to GDP ratio was used as an indicator of banking sector development (see Levine (1997), Asteriou (2003), Shan (2005), and Masih (2008)). This ratio reflects an extensive use of currency out side the banking system rather than an increase in bank deposits. Owing to this reason this measure appears to be less indicative of the financial dealings and transaction of the banking system. Now-a-days researchers are using the ratio of M2 minus currency in circulation to nominal GDP as financial sector development Abu-Bader et al. (2005), Dematriads and Hussen (1996), and Khan et al. (2005). M2 means total currency in circulation in the economy i.e. currency in the tills of scheduled banks, bank deposits with SBP, scheduled banks demand deposits and scheduled banks time deposits .

The second indicator of banking sector development is the ratio of domestic credit to private sector to nominal GDP $(D C P S)$. This indicator measures the quality and quantity of the investment financed by the banking sector many researchers used this indicator as a proxy for financial sector development (see King and Levine (1993), Levine (1999), Abu-Bader,et al. (2005), Beck et al, Shandre, et al. (2004) Mazur and Alexander (2001), Shan (2005), Erdal and Hyougsoo (2007), Acaravci et al. (2007). Third indicator of the banking sector development is the assets with the central bank to GDP ratio (ASBG). Central bank assets are gold, approved foreign exchange and special drawing rights. It further reveals the strength of financial system of a country. Average market capitalization to GDP ratio $(A M C)$ is used as the indicator of development of stock exchange market. Thus ratio of total value of stock market over the nominal GDP shows the country's financial and investment policy behavior (Beck et al.1999). Sustainable economic development is measured by the ratio of external debt to exports ratio $(E D X)$. This indicator represents the degree of indebtedness of the country and its exports performance. Higher the ratio, greater the share of the GDP allocated to current repayments and a burden on future generations, As a result, the economy's current and future development possibilities will be affected. High indebtedness ratio could curtail social sector spending in the long run. The impact of the reduced spending in social sectors would affect poverty, health and education.

Labels assigned to all the variables used in the study are shown in the table 1.

\subsubsection{Test for Stationarity Check}

Stationarity is a key concept used in econometric theory for the time series data as regressions between two non-stationary variables produce bogus results according to (Griffith et al. 2001). Most time series show the increasing or decreasing tendency over the time. Any estimation between series depicting specific inclinations may turn out to have considerable results with high $\mathrm{R}^{2}$, but may not be authentic (Granger and Newbold, 1974). To 
avoid all these problems of the spurious regression results; Dickey Fuller and Augmented Dickey Fuller test (1986) are used for stationarity check of all the variables.

\subsubsection{Test for Cointegration}

The concept of cointegration was first given by Granger (1981). If the linear combination of two non- stationary I (1) series, $\mathrm{Y}$ and $\mathrm{X}$, such that the residuals of the regression are stationary, errors have tendency to disappear and return to zero i.e. are I $(0)$, then the variables are co integrated.

$$
\begin{aligned}
& Y_{t}=\beta_{0}+\beta_{1} X_{t}+u_{t} \ldots \ldots \ldots \ldots(1) \\
& u_{t}=Y_{t}-\beta_{0}-\beta_{1} X_{t} \ldots \ldots \ldots \ldots(2) \\
& u_{t}=I(0) \ldots \ldots \ldots \ldots \ldots \ldots \ldots \ldots \ldots \ldots \ldots \ldots \ldots \ldots
\end{aligned}
$$

Auto regressive distributed (ARDL) bounds testing approach is applied to examine the cointegration relationship between financial sector development and economic development.

$$
E D X_{t}=b_{0}+b_{1} M G_{t}+b_{2} A M C_{t}+b_{3} A S B G_{t}+b_{4} D C P S_{t}+e_{t} \text {. }
$$

Following double log form is used to estimate the cointegration relationship between financial sector development and sustainable development (loyaza, 2002).

$$
L n E D X_{t}=b_{0}+b_{1} L n M G_{t}+b_{2} L n A M C_{t}+b_{3} L n A S B G_{t}+b_{4} L n D C P S_{t}+e_{t} \ldots \ldots \text { (5) }
$$

\subsection{Estimation Procedure}

The study uses Auto Regressive Distributed Lag (ARDL) bound testing approach to cointegration developed by Pesaran (2001). ARDL has many advantages over Johansen cointegration approach. It can be applied when the variables are of different order of integration, Variables may be I (0), I (1) or mutually co integrated (Pesaran and Pesaran, 1997). This approach performs better than Engle Granger or Johansen cointegration technique in small sample size. In ARDL approach all the variables are considered as endogenous variables.

To find out the cointegration relationship between financial sector indicators and the economic development the following unrestricted error correction version of the ARDL model is used. The auto regressive distributed lag approach to cointegration is a general to specific approach. Numbers of iterations are made and lag length is selected that provided appropriate estimates.

$$
\begin{aligned}
& D L n E D X_{i t}=b_{0}+\sum_{i=1}^{p} b_{1 i} D \operatorname{LnEDX} X_{t-i}+\sum_{i=1}^{p} b_{2 i} D L n M G_{t-i}+\sum_{i=1}^{p} b_{3 i} D L n A M C_{t-i} \\
& +\sum_{i=1}^{p} b_{4 i} D L n D C P S_{t-i}+\sum_{i=1}^{p} b_{5 i} D \operatorname{LnASBG} t_{t-i}+l_{1} \operatorname{LnEDX} X_{t-1}
\end{aligned}
$$$$
+l_{2} L n M G_{t-1}+l_{3} \operatorname{LnAMC} C_{t-1}+l_{4} \operatorname{LnDCPS} t_{t-1}+l_{5} \operatorname{LnASB} G_{t-1}+m_{t} \ldots
$$

In equation (6), the terms with the summation signs represent the error correction dynamics (short run dynamics of the model), and the terms with $\lambda$ sign represent the long run relationship. While $\beta o$ is the drift component and $\mu_{t}$ the white noise error term.

The null hypothesis indicating the non existence of long run relationship is used as follows

$$
H o: \lambda_{1}=\lambda_{2}=\lambda_{3}=\lambda_{4}=\lambda_{5}=0 \ldots \ldots \text {. } 7 \text { ) }
$$

The alternative hypothesis shows the existence of the long run relationship among the variables. $H_{1}: \lambda_{1} \neq \lambda_{2} \neq \lambda_{3} \neq \lambda_{4} \neq \lambda_{5} \neq 0 \ldots \ldots$ (8)

The null hypothesis is estimated through the help of F statistics. Two asymptotic critical value bands are provided by Pesaran et al (2001) when the variables are $\mathrm{I}(0)$ or $\mathrm{I}(1)$. The assumption considered by the lower boundary is that variables in the model are I(0) and the upper boundary assumes that all the variables in the model were I(1). If some concerned variables are I (2) or beyond, then the computed F statistics provided by Pesaran et al. (2001) becomes invalid.

The ARDL approach starts with conducting the bounds test for the null hypothesis of no co integration. The Fstatistic is compared with the critical value tabulated by Pesaran et al. (2001). If computed F- statistic exceeds the upper critical value the null hypothesis of no long run relationship can be rejected regardless of whether the order of integration of the variables is I(0) or I(1). Similarly if calculated F- statistic is below the lower critical value, the null hypothesis is failed to reject. If calculated F- statistic is between these two bounds the results would be inconclusive. When the long run relationship is established among the variables then there is an error correction representation.

So the following error correction model is estimated. 


$$
\begin{aligned}
& D L n E D X_{t}=b_{0}+\sum_{i=1}^{p} b_{1 i} D \operatorname{LnEDX} X_{t-i}+\sum_{i=1}^{p} b_{2 i} D L n M G_{t-i}+\sum_{i=1}^{p} b_{3 i} D \operatorname{LnAMC} C_{t-i} \\
& +\sum_{i=1}^{p} b_{4 i} D \operatorname{LnDCPS} S_{t-i}+\sum_{i=1}^{p} b_{5 i} D \operatorname{LnASB} G_{t-i}+a E C M_{t-1}+m_{t} \ldots \ldots . . .(9)
\end{aligned}
$$

The error correction model results indicate the speed of adjustment back to long run disequilibria after a short run shocks. The ECM integrates the short-run coefficient with the long-run coefficient with out losing long-run information

\subsubsection{Test for Granger Causality}

There are two variables $y_{t}$ and $M_{t}$ affecting each other with distributed lags; the relationship between these variables can be captured by a VAR model

There are four possibilities that (a) $y_{t}$ causes $M_{t}$ (b) $M_{t}$ causes $y_{t}$ (c) there is a bi-directional feedback (causality among the variables) (d) the two variables are independent.

\subsubsection{Test for Stability Check}

The goodness of fit of the ARDL model is verified through the stability tests namely Cumulative Sum of Recursive Residuals (CUSUM) and Cumulative Sum of Squared Recursive Residuals (CUSUMSQ.). The diagnostic test examined the serial correlation, functional form, normality and heteroscedasticity.

\section{Results and Discussion}

The relationship between time series variables could be estimated by cointegration test. Prior to conducting the cointegration analysis, it is essential to check the Stationarity for each variable in the model. The presence of unit root in time series data usually provides fake regression results (Griffith et al, 2001). Thus, the first step in any time series empirical analysis is to test for presence of unit root to avoid the problem of inaccurate estimates. A series is stationary when the mean and variance is constant and Covariance is time independent. In order to check stationarity, Dickey Fuller and Augmented Dickey Fuller tests (1986) are used. Unit root tests are applied on the original data series and results of the tests are reported in the table 2.

The results of the unit root tests shows that all the variables are non-stationary at level. Tabulated value of all the variables is less negative then the critical values. It shows the existence of unit root i.e. the variables are non-stationary at level. Further the unit root tests were applied on the first differenced time series. The results in the table 3 show that all the variables attained stationarity at first difference. The calculated values of coefficients are more negative then the critical value developed by McKinnon (1991).

\subsection{Cointegration tests}

The null hypothesis of no cointegration is estimated through ARDL approach. The F- statistic is compared with the critical value tabulated by Pesaran et al (2001). The results of variable addition test show that the value of $\mathrm{F}$ statistics i.e. 5.635 at 5 percent level of significance exceeded the critical bounds ( 2.649 to 3.805 ) developed by Pesaran et al. (1997) with an unrestricted intercept and no trend at 95 percent level. So the null hypothesis of no long run relationship is failed to accept (rejected). The rejection of null hypothesis shows the clear long run relationship between the variables of financial sector development and sustainable economic development (EDX).

The co-integrating vectors are generated through application of bounds tests on equation 9. Independent variables are used as dependent variables turn by turn and the value of $\mathrm{F}$ statistics is calculated.

$$
\begin{aligned}
\Delta L n E D X_{t}=\beta_{0}+\sum_{i=1}^{2} \beta_{1 i} \Delta L n E D X_{t-i}+\sum_{i=1}^{2} \beta_{2 i} \Delta L n M G_{t-i}+\sum_{i=1}^{2} \beta_{3 i} \Delta L n A M C_{t-i} \\
+\sum_{i=1}^{2} \beta_{4 i} \Delta \operatorname{LnDCPS} S_{t-i}+\sum_{i=1}^{2} \beta_{5 i} \Delta L n A S B G_{t-i}+\lambda_{1} \operatorname{LnEDX} X_{t-1}
\end{aligned}
$$

$$
+\lambda_{2} L n M G_{t-1}+\lambda_{3} \operatorname{LnAMC}_{t-1}+\lambda_{4} \operatorname{LnDCPS_{t-1}}+\lambda_{5} \operatorname{LnASBG_{t-1}}+\mu_{t}
$$

The results of table 4 indicate the existence of a long run relationship between the variable of financial sector and external debt to exports ratio. Therefore ARDL approach to co integration was applied to estimate the long run coefficients and error correction model. ARDL $(3,1,0,1,1)$ model is estimated and lags are selected based on Schwarz Bayesian Criterion. Dependent variable is log of external debt to exports ratio (LnEDX)

The results indicate that all the variables are significant at 5 percent level of significance but average market capitalization to GDP ratio (AMC) is found insignificant. The sign of credit to private sector to GDP ratio (DCPS) and assets with the State Bank to GDP ratio (ASGB) are negative and consistent with the economic theory; 
indicating the inverse relationship between financial sector development and external debt to exports ratio. An increase in M2 minus currency in circulation indicates that M2 minus currency in circulation was increasing at rapid rate as compared to increase in GDP. It meant people are spending less and saving more to have more financial assets. It leads to saving paradox that is more saving, less investment. The sign of average market capitalization is also negative, consistent with economic theory but insignificant. It is concluded that banking sector is more affective to reduce the ratio of external debt to exports ratio in Pakistan. This model also highlighted the importance of credit to private sector, which had a robust effect on reducing the ratio of external debt to exports ratio. But stock exchange markets show no significant role to reduce external debt to exports ratio. The results are consistent with Roble (1997).

\subsection{Error Correction Mechanism}

The value of error correction coefficient is -0.756 , statistically significant at the 5 percent levels confirms a high speed of adjustment back to long run disequilibrium i.e. with the feedback coefficient of 0.756 . Only the coefficient of assets with the State Bank to GDP ratio is significant with negative sign. It shows that assets with the State Bank had inverse relationship with external debt to exports ratio. Whereas the lagged values of external debt to exports ratio are accumulating the external debt to exports ratio in short run.

\subsection{Granger Causality Tests}

Pair wise Granger Causality Test was applied and the results of the test were given in the following table. The results indicate unidirectional causality between external debt to exports ratio and the ratio of credit to private sector to GDP. Uni-directional causality is also observed between assets with the State Bank of Pakistan to GDP ratio and external debt to exports ratio at 5 percent level of significance. The results of causality test highlighted the importance of credit to private sector and assets with the State Bank, showing

a robust effect on economic development.

\section{Stability of the Model}

The Cumulative Sum of Recursive Residuals (CUSUM) and Cumulative Sum of Squared Recursive Residuals (CUSUMSQ) stability tests are applied to confirm the stability of the variables in the model. Graphs of CUSUM and CUSUMSQ are within 5 percent of critical bands. It indicates the structural stability of the variables of the model (Oskooee and Wing, 2002). The plots of Both CUSUM and CUSUMSQ given in Fig 1 \& Fig 2 confirm the stability of the model.

\section{Conclusion}

The study evaluates the role of financial sector in sustainable economic development of Pakistan. The main objectives of the study are to analyze the long run relationship between financial sector development and sustainable economic development and also to determine the direction of causality between financial sector indicators and sustainable economic development. Dickey Fuller and Augmented Dickey Fuller unit root tests are used to check the stationarity of each variable in the model. All the variables are found I (1). Auto Regressive Distributed Lag (ARDL) bounds testing technique to cointegration, developed by Pesaran et al. (2001) is applied to estimate the long run relationship between financial sector development and sustainable economic development. A stable cointegration relationship is found among the variables and Error Correction coefficient is also found statistically significant. It indicates that there is a stable long run relationship between financial sector and economic development.Short run results indicate that the lagged values of external debt to exports ratio with direct relationship are accumulating the external debt to exports ratio. Uni-directional causality exists between external debt to exports ratio and credit to private sector to GDP ratio and also between assets with the State Bank to GDP ratio and external debt to exports ratio. The study also applied the stability tests, Cumulative Sum of Recursive Residuals (CUSUM) and Cumulative Sum of Squared Recursive Residuals (CUSUMSQ) for the structural stability of the variables in the model and found that the model is stable.

\section{Policy Recommendations}

On the basis of estimated results the study concludes that credit to private sector has a significant impact on sustainable economic development in long run. Therefore priority should be given to private sector in credit disbursement decisions to further enhance the pace of sustainable economic development. The ratio of M2 minus currency in circulation to GDP shows a negative impact on economic development. Savings are essential to economic development, but these savings should be converted into productive investment to get the fruits of development. It was also found that the assets with the State Bank of Pakistan had a significant role to reduce the ratio of external debt to exports. The study suggested that a well-developed financial sector is essential to economic development. Liberal policies should be adopted for the development of financial sector in Pakistan to have the sustainable development of the economy.

\section{References}

Abu-Bader, S. and Abu-Qarn, A. S. (2005). Financial Development and Economic Growth: The Egyptian Experience,Discuusion paperno. 05-14, Monaster cebter for Economic Research,Ben-Gurion Univ. of Negev P.O.Box 653 Beer sheva Israel 1-36. 
Acaravci, A., Ilhan, O. and Acaravci, S.K. (2007). Finance and Growth Nexus: Evidence from Turkey, International Research Journal of Finance and Economics, 11,30-40 http://www.eurojournals.com/finance.htm

Andries, E., Asteriou, D. and Pilbeam, K. (2003). The Linkage between Financial Liberalization and Economic Development: Empirical Evidence from Poland, Discussion Paper Series No.03/03.

Ang, J. B. (2008). Finance and Inequality: The Case of India. Monash University, Department of Economics, Discussion paper 08/08, ISSN 1441-5429.

Arestis, P., Panicos, O. D. and Kul, B. (2001). Financial Development and Economic Growth: The Role of Stock Markets Journal of Money, Credit and Banking, 33, 16-41.

Asteriou,D. and Siriopoulos, C. (2003). The Role of Political Instability in Stock Market Development and Economic Growth:The Case of Greece, Economic Notes by Banca Monte dei Paschi di Siena SpA, 29, 3-2000, 355-374

Bagehot. (1873). A Description of Money Market with Currency Monopoly, Homewood.ILRichard, 1962.

Beck, T., Demirgüç-Kunt, A. and Levine, R. (2000). A New Database on Financial Development andStructure. World Bank Economic Review, 14, 597-605.

Darrat, A. F. (1999). Are Financial Deepening and Economic Growth Causality Related? Another Look at the Evidence. International Economic Journal,13

Dematriads,P.O. and Hussen,K.A. (1996) Does financial development cause economic growth? Time-series evidence from 16 countries, Journal of Development Economics, 51(2),387-411

Emilia A. M. and Alexander,R.W. J. (2001). Financial Sector Development and Economic Growth in New Zealand. Applied Economics Letters, 8, 545- 549.

Granger and Newbold, 1974). Spurious Regression in Econometrics. Journal of Econometrics, 2,111-120.

Granger,C.W.(1986). Developments in the study of co-integrated economic variables. Oxford Bulletin of Economics and Statistics, 48, 213-228.

Griffith et al. (2001).Learning and Practicing Econometric John Wiley\& Sons New York.

Gujrati, D. (2004) Basic Econometrics, Fourth Edition, The McGraw-Hill Companies.

Hermes, N. and Lensink, R. (2003). Foreign Direct Investment, Financial Development and Economic Growth,The Jouranal of Development studies, 40, 142-163

Jalil, A. and Ma, Y. (2008). Financial Development and Economic Growth: Time Series Evidence from Pakistan and China. Journal of Economic Coopration. 29, 2,29-68.

Jayaraman, T. K. and Choong, C. K. (2007). Financial Sector Development and Growth in Fiji: An Analysis of Credit Boom and Its Implications, Asia Pacific Economic Journal,5, 1,1-20.

Johansen, S. 1988. Statistical analysis of cointegration vectors. Journal of Economic Dynamics Control, 12, pp. 231-254.

Johansen, S. and Juselius, K. (1990). Maximum likelihood estimation and inference on cointegration- with applications to the demand for money. Oxford Bulletin of Economics and Statistics, 52, pp. 169-210.

Khan, M. A. and Qayyum, A. (2004), Trade, Financial and Growth Nexus in Pakistan, Economic Analysis Working Papers. 6,14., 1-24

Khan, M. A. Qayyum, A. and Sheikh, S. A. (2005). Financial Development and Economic Growth: The Case of Pakistan. The Pakistan Development Review,44,4,819-837.

King, R. G. and Levine, R. (1993). Finance and Growth: Schumpeter Might be Right ,The Quarterly Journal of Economics, 108, 3, 717-737.

Levine, R. (1997).Financial Development and Economic Growth: Views and Agenda. Journal of Economic Literature,35, 688-726.

Levine, R. and Zervos, S. (1998). Stock Markets, Banks, and Economic Growth, The American Economic Review. $88,3,537-558$.

Ljungwall, C. and Li, J. (2007). Financial Sector Development, FDI and Economic Growth in China. working paper series, No. E 2007005.

Loayza, R. and Ranciere, R. (2002). Financial Development, Financial Fragility, and Growth, CESifo Working Paper 684 (5).

Masih,A.M. and Masih, R. (2008). Intra-Market Price Discovery in an Emerging Stock Market: Vector Fractionally-Integrated Error Correction Model and Toda-Yamamoto Level VAR Approaches, Asian Journal of Business and Accounting,1(1), 93 - 112

McKinnon, J.J. (1991). Critical values for cointegration tests in (Eds.). in R.F Engel and C.W. Granger (Eds.) Long run economic relationships; Readings in cointegration, Oxford:, Oxford university Press, 1991 pp. 267-276 
Bahmani-Oskooee,M. and Wing Ng,R,C.(2002). Long-Run Demand for Money in Hong Kong:An Application of the ARDL Model, International Journal of Business and Economics, 1,2, 147-155

Pesaran, M. H. and B. Pesaran. (1997). Microfit 4.0: Interactive Econometric Analysis, Oxford: Oxford University Press.

Pesaran, M. H., Shin Y. and Smith, R.J. (2001). Bounds testing approaches to the analysis of level relationships. Journal of Applied Econometrics, 16, 289-326

Robles, S. B. (1997). Financial Efficiency and Economic Growth: The Case of Spain , International Advances in Economic Research. 3,4,333-351

Schumpeter, J. 1912. "The Theory of Economic Development”, Havard University Press,

Seetanah, B. (2007). Financial Development and Economic Growth: an ARDL approach for the case of the Small Island state of Mauritius. Applied Economics Letters,----,1-5.

Shahbaz, M., Ahmed, N. and Liaquat, A. (2008).Stock Market Development and Economic Growth: ARDL Causality in Pakistan. International Research Journal of Finance and Economics, 14,182-195

Shan, J. (2005). Does Financial Development 'lead' Economic Growth?: A Vector Auto-Regression Appraisal, Applied Economics, 37, 1353-1367.

Shandre, M. Thangavelu, and, James, A. B. J. (2004), Financial development and economic growth in Australia: An Empirical Analysis, Empirical Economics 29, 247-260.

Notes

Note 1. Among them are Bagehot(1873),Schumpeter(1912), Levine (1997), Beck,et al.(2000) Arestis et al.(2001), Shan et al. (2005), and Abu-Bader and Abu-Qarn (2007).

Table 1. Labels Assigned to Variables of the Study

\begin{tabular}{|l|l|}
\hline Label & Name of the variable \\
\hline$L n M G$ & Log of M2 minus currency in circulation to GDP ratio. \\
\hline$L n A M C$ & Log of Average Market Capitalization to GDP ratio. \\
\hline$L n D C P S$ & Log of domestic credit to private sector to GDP ratio. \\
\hline$L n A S B G$ & Log of assets with the State Bank of Pakistan to GDP ratio. \\
\hline$L n E D X$ & Log of external debt to exports ratio. \\
\hline
\end{tabular}

Table 2. Results of the Unit Root Test at level

\begin{tabular}{|l|l|l|l|l|}
\hline & \multicolumn{2}{|l|}{ Test with a constant \& no trend } & \multicolumn{2}{l|}{ Test with a constant \& trend } \\
\hline Variables & DF & ADF & DF & ADF \\
\hline LnMG & -0.796 & -0.783 & -2.092 & -2.224 \\
\hline LnAMCG & 0.996 & 0.197 & -2.307 & -2.234 \\
\hline LnASBG & -1.080 & -1.040 & -2.199 & -2.243 \\
\hline LnDCPS & -2.114 & -2.740 & -2.265 & -2.873 \\
\hline LnEDX & -1.279 & -2.23 & -1.362 & -2.312 \\
\hline Critical value & -2.953 & -3.551 & \\
\hline
\end{tabular}

At 5 percent level of significance.

Table 3. Results of the Unit Root Test at first Difference level

\begin{tabular}{|l|l|l|l|l|}
\hline & \multicolumn{2}{|l|}{ Test with a constant and no trend } & \multicolumn{2}{l|}{ Test with a constant and trend } \\
\hline Variables & DF & ADF & DF & ADF \\
\hline DLnMG & $-5.497^{*}$ & $-4.389^{*}$ & $-5.448^{*}$ & $-4.356^{*}$ \\
\hline DLnAMCG & $-5.680^{*}$ & $-3.625^{*}$ & $-5.708^{*}$ & $-3.654^{*}$ \\
\hline DLnASBG & $-5.493^{*}$ & $-4.082^{*}$ & $-5.346^{*}$ & $-3.913^{*}$ \\
\hline DLnDCPS & $-5.769^{*}$ & $-5.514^{*}$ & $-5.686^{*}$ & $-5.380^{*}$ \\
\hline DLnEDX & $-3.681^{*}$ & $-2.974^{*}$ & $-3.616^{*}$ & $-3.913^{*}$ \\
\hline Critical value & -2.956 & -3.556 & \\
\hline
\end{tabular}

Note: * indicated the stationarity of the variables at $5 \%$ level of significance. 
Table 4. Results of the Bounds Tests on Changing the Positions of Independent and Dependent Variables.

\begin{tabular}{|l|l|l|l|}
\hline Dependent variable & Independent variable & Value of F statistics & Lags order \\
\hline LnMG & LnEDX, LnAMC, LnDCPS, LnASBG & $4.2477^{*}$ & 3 \\
\hline LnAMC & LnEDX, LnMG, LnDCPS, LnASBG & 1.1560 & 2 \\
\hline LnDCPS & LnEDX, LnMG, LnAMC, LnASBG & 3.6131 & 1 \\
\hline LnASBG & LnEDX, LnMG, LnDCPS, LnAMC & $3.8173^{*}$ & 2 \\
\hline
\end{tabular}

Note: ${ }^{*}$ represented the co integration relationship.

Table 5. Results of Long run Relationship between Sustainable Development (external debt to exports ratio) and Financial Sector Development

\begin{tabular}{|l|l|l|l|}
\hline Independent variable & Coefficient & Standard Error & T-Ratio \\
\hline LnMG & $0.642^{*}$ & 0.164 & 3.901 \\
\hline LnAMC & -0.024 & 0.039 & -0.627 \\
\hline LnDCPS & $-0.620^{*}$ & 0.294 & -2.105 \\
\hline LnASBG & $-0.283^{*}$ & 0.054 & -5.185 \\
\hline INPT & 7.299 & 0.975 & 7.483 \\
\hline
\end{tabular}

Note: * indicated 5 percent level of significance.

Table 6. Short term Dynamics between Sustainable Development and Financial sector development through Error Correction Model

$\log$ of external debt to exports ratio is used as dependent variable

\begin{tabular}{|l|l|l|l|}
\hline Independent Variables & Coefficient & Standard Error & T-Ratio \\
\hline DLnEDX1 & 0.230 & 0.152 & 1.518 \\
\hline dLnEDX2 & $0.591^{*}$ & 0.181 & 3.273 \\
\hline dLnMG & -0.248 & 0.215 & -1.152 \\
\hline dLnAMC & -0.018 & 0.030 & -0.616 \\
\hline dLnDCPS & -0.015 & 0.239 & -0.063 \\
\hline dLnASBG & $-0.097^{*}$ & 0.038 & -2.563 \\
\hline dINPT & 5.523 & 1.184 & 4.6643 \\
\hline ecm(-1) & $-0.756^{*}$ & 0.133 & -5.697 \\
\hline R-Squared & 0.762 & & \\
\hline DW-statistic & 2.223 & \\
\hline
\end{tabular}

Note: * indicated 5 percent level of significance.

Table 7. Granger Causality between Sustainable Development and Financial Sector development $\log$ of external debt to exports ratio is used as dependent variable

\begin{tabular}{|lll|l|l|}
\hline \multicolumn{2}{|c|}{ Direction of Causality } & F-Statistic & Probability \\
\hline LnMG & NO & LnEDX & 1.033 & 0.318 \\
\hline LnEDX & NO & LnMG & 1.6352 & 0.211 \\
\hline LnAMC & NO & LnEDX & 0.1052 & 0.748 \\
\hline LnEDX & NO & LnAMC & 1.794 & 0.190 \\
\hline LnDCPS & NO & LnEDX & 0.495 & 0.488 \\
\hline LnEDX & \multicolumn{2}{c|}{ LnDCPS } & $13.694^{*}$ & 0.001 \\
\hline LnASBG & \multicolumn{2}{|c|}{ LnEDX } & $3.954^{*}$ & 0.056 \\
\hline LnEDX & NO & LnASBG & 0.697 & 0.410 \\
\hline
\end{tabular}

Note: * indicates 5 percent level of significance. 


\section{Plot of Cumulative Sum of Recursive Residuals}

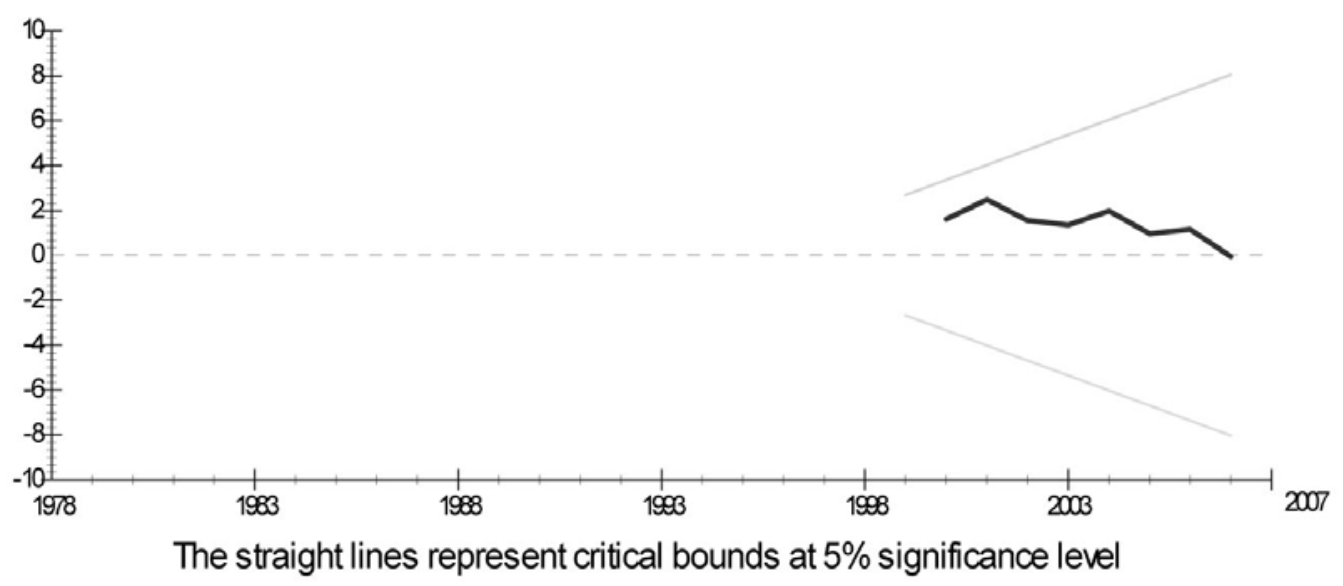

Figure 1. Plot of CUSM recursive residuals showing stability of Model

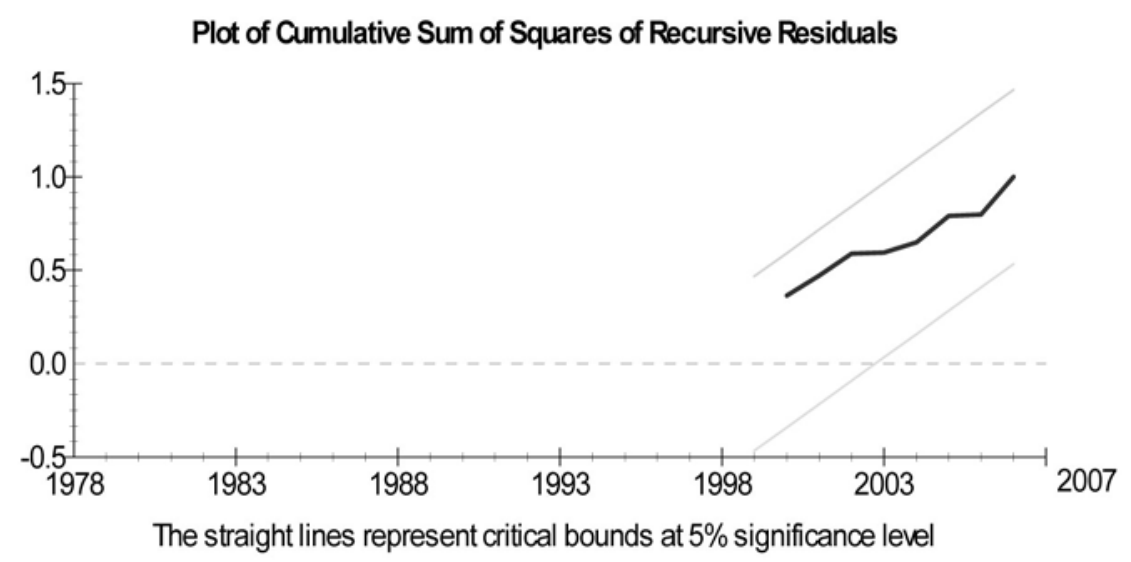

Figure 2. Plot of CUSMSQ Recursive residuals showing stability of Model 